\section{Perspectives on physical geology}

Physical (iEOLOGY, defined by $S$. Judson et al. in Physical Geology (Prentice-Hall: Englewood Cliffs, New Jersey, \$14.50) as a discipline which "addresses itself to the composition, classification and origin of earth materials, and to the physical and chemical processes which go on at or beneath the earth's surface", covers a formidable range of material. At the small scale it deals with soil creep and at the other global tectonics. In addition it seems that under its umbrella one must attempt to cope with the study of resources, with environment, and with the characteristics of other planets.

It would be remarkable, given the scope that this offers, if three books on physical geology were to cover the same material in broadly the same way. Three recently published volumes however, are remarkable in just such a way. They have plainly been aimed at the same market (majors and nonmajors in a one-semester or one-term course at the American college level): they have broadly similar format (multi-colour printing, many illustrations, good type); they all attempt to cover similar ground, and they all make commendable efforts to be comprehensible and attractive.

The differences between them are of a cosmetic rather than a fundamental nature. J. H. Zumberge and C.. A. Nelson in Elements of Physical Geology (Wiley: New York and London, £7.20; $\$ 14.40$ ) offer the best colour illustrations of rock types and minerals together with an illustration of a seemingly topless Hawaiian surfer. J. E. Sanders et al. in Physical Geology (Harpers College, Harper and Row: I.ondon and New York, £10.45) offer flip drawings of Pangaea on the top corners of some $\mathbf{4 0}$ pages to "present the idea of drifting continents as vividly as possible", together with extracts from other writers (which they term "field trips"). And Judson et al. both pose and answer questions for the student, but (presumably why on a page for page basis they are cheapest) they offer slightly less glitter.

A second remarkable feature of such books would be for them to range successfully and adequately across the great range of material they seek to cover. Broadly speaking all of them do this, and broadly speaking their content and their guides to further reading are up-to-date. They all seek to put across the rudiments of mineral characteristics, rock types, volcanoes, weathering, mass movement processes, rivers, orogeny and plate tectonics.
Judson et al. use the plate tectonics concept as a framework for much of their discussion whereas it is less prominent in Zumberge and Nelson and in Sanders et al.

Inevitably there are inadequacies, omissions or lack of awareness of recent work. Rates of geomorphic processes are consistently neglected; climatic changes are given scant attention: coral reefs are accorded little prominence; Davis's great cycle of erosion is relegated to the very briefest of mentions; and the nature of water movement in drainage basins (particularly throughflow and runoff genera-

\section{Structural geology}

An Outline of Structural Geology by B. R. Hobbs, W. D. Means and P. F. Williams (Wiley: New York and London, $\$ 20 ; £ 10)$ is intended to replace Sherbon Hills' Outlines (Prentice-Hall, 1972) as a comprehensive text on structural geology for undergraduates. The involvement of three authors, all well known and experienced research workers, is perhaps a comment on the rapid growth in the complexity and diversity of the subject over recent years. Some years ago structural geologists were chided with scientific myopia, specifially, for having 'played' with minutiae while others discovered plate tectonics. Fair comment or not, this reminds us that when subjects develop toward a labyrinth of narrow specialisations there is an urgent need for a survey of the whole field of activity.

The plan of this book is not novel, indeed it has much the same lay-out as Sherbon Hills' and its success depends on the quality of treatment of familiar topics. It starts with mechanical aspects and stress-strain theory, and progresses from minor structures (microfabrics) through folds, faults, foliation and lineation to major structures and, finally, plate tectonics. The 'bridge' from small to large is in parts of a useful, but rather brief, chapter on "structural associations", that is thrust belts, block faulted regions, and so on. There is also an essential chapter on geometrical analysis and this topic, including stereographic analysis, is continued in an appendix.

It is a pleasure to record that the authors' surefooted approach, with its mingling of fact and comment, hardly ever lets them down. Fortunately, the authority which is evident in individual sections of the book is not spoilt by any overall lack of balance which is I suppose a danger when several authors are involved. Of course it is not perfect. For this reader, the splendid section on microfabrics is not always tion) is hopelessly out-of-date in the way that it is treated.

Overall there is not a great deal to choose between these three texts. They all offer clear, well-produced introductions to their views of physical geology. Probably their main use in Britain will be as texts for sixth-formers, but most University undergraduates would find shorter texts covering specialised topics at a greater depth more useful.

Andrew Goudie

Andrew Goudie is Lecturer in the School of Geography at the University of Oxford, $\boldsymbol{U} \boldsymbol{K}$.

matched elsewhere in the book and it is surprising to find so little on fluid pressures, or on pressure solution, or on techniques for estimating strain, shortening and displacement in orogens. My impression is that the authors are happier on the minor structures than with major structural phenomena. Their chapter on plate tectonics, however, is quite admirable.

The illustrations are vital in a book on structural geology and here there are many excellent diagrams and photographs, and very few disappointments.

The authors have Jesigned their book for undergraduates. There are several potential rivals even if we exclude $\mathbf{J}$. G. Ramsay's classic advanced book (Folding and Fracturing of Rocks, McGrawHill, 1967) and that by F. J. Turner and L. E. Weiss (Structural Analysis of Metamorphic Tectonites, McGraw-Hill, 1963), which has never been suitable at this level. The most recent editions of the respected books by L. U. de Sitter (Structural Geology, McGraw-Hill, 1964) and M. P. Billings (Structural Geology, Prentice-Hall, 1972) cannot be considered as truly modern in approach.

The books by E. W. Spencer (Introduction to the Structure of the Earth, McGraw-Hill, 1969) and P. C. Badgley (Structural and Tectonic Principles, Harper and Row, 1965) share some of the virtues of de Sitter's book in that they include 'potted' accounts of classic regions for the study of deformed rocks and this must be an asset for the hard pressed undergraduate. But the present book must surely take precedence over these because it goes further toward the goal of presenting structural geology, not only in modern terms but also as a coherent subject based on physicochemical laws. I think the research worker will also benefit from this reliable and well produced book.

M. R. W. Johnson

M. R. W. Johnson is Reader at the Grant Institute of Geology, University of Edinburgh, UK. 